\title{
DO LEADERS MATTER? NATIONAL LEADERSHIP AND GROWTH SINCE WORLD WAR II*
}

\author{
Benjamin F. Jones and Benjamin A. Olken
}

Economic growth within countries varies sharply across decades. This paper examines one explanation for these sustained shifts in growth-changes in the national leader. We use deaths of leaders while in office as a source of exogenous variation in leadership, and ask whether these plausibly exogenous leadership transitions are associated with shifts in country growth rates. We find robust evidence that leaders matter for growth. The results suggest that the effects of individual leaders are strongest in autocratic settings where there are fewer constraints on a leader's power. Leaders also appear to affect policy outcomes, particularly monetary policy. The results suggest that individual leaders can play crucial roles in shaping the growth of nations.

"There is no number two, three, or four . . There is only a number one: that's me and I do not share my decisions."

—Felix Houphouet-Boigny, President of Cote D’Ivoire (1960-1993)

\section{INTRODUCTION}

In the large literature on economic growth, economists have given little attention to the role of national leadership. While the idea of leadership as a causative force is as old if not older than many other ideas, it is deterministic country characteristics and relatively persistent policy variables that have been the focus of most econometric work. ${ }^{1}$

Recent research, however, suggests that countries frequently experience dramatic reversals in growth, so that a country's growth in one decade is often little related to growth in the next [Easterly et al. 1993; Pritchett 2000]. These reversals are an important part of the growth experience for many countries,

* The authors would like to thank Daron Acemoglu, Alberto Alesina, Abhijit Banerjee, Robert Barro, Francesco Caselli, Esther Duflo, Amy Finkelstein, Edward Glaeser, Michael Gordin, Bryan Graham, Charles Jones, Lawrence Katz, Michael Kremer, Sendhil Mullainathan, Lant Pritchett, Xavier Sala-i-Martin, Scott Stern, and four anonymous referees for helpful comments. Sonia Chan, Sidney Henderson, Jessica Huang, Tabinda Khan, Ellen Kim, Patricia Reiter, Thomas Wang, and Jacqueline Yen all provided invaluable research assistance. The support of the George Shultz Fund for the data collection is gratefully acknowledged. Jones also acknowledges support from the Social Science Research Council's Program in Applied Economics, with funding provided by the John D. and Catherine T. MacArthur Foundation, and Olken acknowledges support from the National Science Foundation Graduate Research Fellowship.

1. See, for example, Sachs and Warner [1997] on geography, Easterly and Levine [1997] on ethnic fragmentation, La Porta et al. [1999] on legal origin, and Acemoglu, Johnson, and Robinson [2001] on political institutions.

๑ 2005 by the President and Fellows of Harvard College and the Massachusetts Institute of Technology.

The Quarterly Journal of Economics, August 2005 
particularly in the developing world. Moreover, the explanations for such reversals are not likely to be found in the slow-moving explanatory variables typically used in the cross-country growth literature. Shocks or higher frequency events can presumably provide better explanations.

This paper asks whether national leaders, who change sharply and at potentially high frequency, have a causative effect on growth. In addition to informing our understanding of the growth process, this question also relates to an old debate over the relative roles of individuals and historical forces in shaping outcomes. From this latter perspective, looking at growth outcomes sets the bar for individual leaders quite high. One might believe that leaders can influence various government policies long before one is willing to believe that leaders could impact something as large as aggregate economic growth.

To examine whether leaders can affect growth, one can investigate whether changes in national leaders are systematically associated with changes in growth. The difficulty, of course, is that leadership transitions are often nonrandom, and may in fact be driven by underlying economic conditions. For example, there is evidence in the United States that incumbents are much more likely to be reelected during economic booms than during recessions [Fair 1978; Wolfers 2001]. Other research has found, in cross-country settings, that high growth rates inhibit coups [Londregan and Poole 1990]. ${ }^{2}$

To solve this problem, we focus our examination on cases where the leader's rule ended at death due to either natural causes or an accident. In these cases, the timing of the transfer from one leader to the next was essentially random, determined by the death of the leader rather than underlying economic conditions. These deaths therefore provide an opportunity to examine whether leaders have a causative impact on growth.

This paper uses a data set on leaders collected by the authors. We identified all national leaders worldwide in the postWorld War II period, from 1945 to 2000, for whom growth data were available in the Penn World Tables. For each leader, we also identified the circumstances under which the leader came to and went from power. Using the 57 leader transitions where the

2. Although other literature has found that growth rates have little predictive power in explaining the tenure of leaders more generally [Bienen and van de Walle 1991]. 
leaders' rule ended by death due to natural causes or an accident and where growth data were available, we find robust evidence that leaders matter. Growth patterns change in a sustained fashion across these leadership transitions. The magnitude of these changes is large; the estimates imply that a one standard deviation change in leader quality leads to a growth change of 1.5 percentage points per year.

We then examine whether leaders matter more or less in different contexts. In particular, one might expect that the degree to which leaders can affect growth depends on the amount of power vested in the national leader. We find evidence that the death of leaders in autocratic regimes leads to changes in growth while the death of leaders in democratic regimes does not. Moreover, among autocrats, leader effects appear more pronounced when leaders have fewer constraints on their power.

We also examine what policies appear to change when leaders change, and find that leaders do affect some policy outcomes. In particular, we find substantial effects of leaders on monetary policy, while we see at best ambiguous evidence for changes in fiscal policy and trade policy. Interestingly, we find no unusual changes in either external conflicts or civil wars associated with leader deaths, though the fact that these events are relatively rare means we may not have sufficient statistical power to detect conflict effects in our sample.

The remainder of this paper is organized as follows. Section II discusses existing literature and debates about the role of national leaders. Section III presents the empirical methodology used in the paper. Section IV presents the main results of the impact of national leaders on their nations' growth. Section V examines how country-level characteristics affect the degree to which leaders matter. Section VI examines what policies seem to be affected by individual leaders. Section VII concludes.

\section{Individuals, Determinism, and the Historical Debate}

The debate over the relative roles of individuals and deterministic forces in shaping historical outcomes is both old and unsettled. Within this debate, authors range from absolutist stances to more moderate, inclusive ones. At one extreme, Tolstoy's historical theory is perhaps the most dismissive of leaders, seeing so-called historic figures as mere ex post justifications for events wholly beyond any individual's influence [Berlin 1978]. 
Marx, in his Eighteenth Brumaire of Louis Napoleon [1852], allows some minimal agency for leaders but argues that leaders must choose from a historically determined set of choices, which means that they have much less freedom to act than they think they do. More broadly, Marx's materialist dialectic continues to inspire many thinkers who see the contest of social or economic forces trumping the roles of individuals. These traditions often see leaders as merely symbolic: "labels" to describe particular expressions of underlying social phenomena. To Tolstoy, Marx, and others, leaders typically claim immodest powers, although they are in fact of little consequence. Meanwhile, the population at large-and historians in later analysis-may accept this pretense as part of a long tradition, ingrained through religious faith, of believing in a higher power [Tolstoy 1869]. A modern view of leadership in the psychology literature considers the very idea of powerful leaders a social myth, embraced to satisfy individuals' psychological needs [Gemmill and Oakley 1992].

In contrast, there are absolutist extremes in which individuals are seen as the decisive influences in history-the so-called "Great Man" view. From this perspective, the evolution of history is largely determined by the idiosyncratic, causative influences of certain individuals, and perhaps a very small number. Carlyle [1837, 1859] articulated this historical theory clearly in his study of the French Revolution and later works, and it perseveres today especially among military historians, who tend to see the individual leader as the key to military outcomes. For example, the British historian John Keegan [2003] has written that the political history of the twentieth century can be found in the biographies of six men: Lenin, Stalin, Hitler, Mao, Roosevelt, and Churchill. ${ }^{3}$

These extremely different historical viewpoints cloud a possible broad middle ground. Berlin [1978] distinguishes in the debate over historical determinism between the singular approach of the "hedgehogs" and the flexibility of the "foxes." In Berlin's menagerie, Marx and Carlyle are hedgehogs. Weber, whose sociological theories act as a counterpoint to Marx on many dimensions, is a fox. Weber [1947] sees a role for "charismatic" leadership in certain circumstances. He allows for possibly sub-

3. Outside of military history, the great man view fell out of fashion for many historians in the twentieth century, its demise related to the seeming inevitability of World War I and Butterfield's [1931] broad attack, The Whig Interpretation of History, on earlier historical reasoning. 
stantial individual roles, but only in those cases where the national bureaucracy, or possibly traditional social norms, do not stand in the way of the individual. For Weber, individuals, historical forces, and institutions are all important, and they interact in an important way.

The texture of this possible middle ground has been investigated most extensively in political science, with particular attention to the ability of institutions to restrain leaders in democracies. The possibility of profound restraints on a democratic leader's power is raised from one direction-leadership selection-in Schumpeter's [1950] observation that political leaders must compete for electoral votes, an idea that can produce decisive constraints through the median voter theorem [Downs 1957]. More broadly, the presence of many "veto players," either constitutionally based institutions or opposing political parties, may severely constrain the action space of leaders and policy outcomes [Tsebelis 2002]. On the other hand, there is evidence that, in the context of legislatures, politicians are not fully constrained by electoral pressures, allowing some room for personal ideological views and party affiliations (see, for example, Kalt and Zupan [1984], Poole and Rosenthal [1984], Levitt [1996], and Lee, Moretti, and Butler [2004]). All told, the evidence suggests that the degree to which political leaders may affect economic outcomes may depend on the institutional context.

Meanwhile, the rapidly expanding literature on economic growth has paid little formal attention to the role of individual leaders. Recent growth research has, however, building on North [1990], moved beyond conceptions of convergence based on purely economic factors to consider the role of institutions and social context in shaping economic outcomes. Among other results, this literature has found relationships between some measures of political institutions and macroeconomic outcomes [Keefer and Knack 1995; Hall and Jones 1999; Quinn and Woolley 2001; Acemoglu, Johnson, and Robinson 2001], although convincingly identifying the causal effects of institutions is difficult [Glaeser et al. 2004]. But if institutions have explanatory power, it is then perhaps a natural next step to ask whether national leaders, who may partly control or substitute for formal institutions, exert personal influences on growth. ${ }^{4}$

4. If the economics literature takes the idea that individual personalities matter seriously, it is primarily in the management literature, which has seen 
In this paper we study national leaders explicitly and find that leaders do matter. In particular, our statistical tests reject the deterministic view where leaders are incidental to the evolution of their national economies. At the same time, we find that leader effects are limited to those settings in which they are relatively unconstrained. Changes in leaders in democracies appear to have no effect on economic growth. Leaders in autocracies, however, and particularly those without parties or legislatures to contest their rule, appear to have very large effects on growth. Thus, our results fall most closely with Weber; leaders matter, but only in settings where other institutions are weak.

In the following sections we develop our methodology, present our results, and examine the interaction of leader effects with descriptions of their institutional constraints.

\section{Methodology}

The key question in this paper is whether growth rates change in a statistically significant manner across randomly timed leader deaths. In this section we derive two tests for whether leaders matter, a standard Wald test and a nonparametric Rank test.

To begin, consider the following growth process:

$$
g_{i t}=v_{i}+\theta l_{i t}+\varepsilon_{i t},
$$

where $g_{i t}$ represents growth in country $i$ at time $t, v_{i}$ is a fixedeffect of country $i$, and $\varepsilon_{i t}$ is a normally distributed error term with mean 0 and variance $\sigma_{\varepsilon i}^{2}$. The term $l_{i t}$ represents leader quality, which is fixed over the life of the leader. Leaders are selected as follows:

$$
l_{i t}=\left\{\begin{array}{ll}
l_{i t-1} & P\left(\delta_{0} g_{i t}+\delta_{1} g_{i t-1}+\cdots\right) \\
l^{\prime} & 1-P\left(\delta_{0} g_{i t}+\delta_{1} g_{i t-1}+\cdots\right)
\end{array},\right.
$$

where $l^{\prime}$ is normally distributed, with mean $\mu$, variance $\sigma_{l}^{2}$, and $\operatorname{corr}\left(l, l^{\prime}\right)=\rho$. The fact that the probability of a leader transition can depend on growth captures the idea that, in general, leader transitions may be related to economic conditions. 
The question we wish to answer is whether $\theta=0$ or not; i.e., whether leaders have an impact on economic outcomes. If leader transitions were exogenous, a natural approach would be to look at the joint significance of leader fixed effects-i.e., dummy variables for each value of $l_{i t}$-to see whether there were systematic differences in growth associated with different leaders. Given the endogeneity of leader transitions, however, this test may find significant results even under the null that $\theta=0$, because leadership transitions, and thus the end dates of the leader fixed effect, may be related to atypical realizations of growth.

Comparing the difference in these fixed effects across leadership transitions caused by leader deaths solves part of the problem, as the date of the transition between leaders is now exogenously determined with respect to growth. However, the other end of the fixed effect for these leaders is still endogenously determined. Therefore, rather than compare differences in fixed effects, we compare differences in dummies that are true in the $T$ periods before the death and in the $T$ periods after the leader death.

In particular, denote by $\overline{P R E}_{z}$ average growth in the $T$ years before a leader death in year $z$, and denote by $\overline{P O S T}_{z}$ average growth in the $T$ years after the leader dies. ${ }^{5}$ Then the change in growth across the leader transition in country $i$ will be distributed:

$$
\widehat{P O S T-P R} E_{z} \sim N\left(0,2 \frac{\sigma_{\varepsilon i}^{2}}{T}+2 \theta^{2} \sigma_{l}^{2}(1-\rho)\right) .
$$

The variance of $P O S T-P R E_{z}$ is equal to the sampling variance, $2 \sigma_{\varepsilon i}^{2} / T$, plus the variance from the expected difference in leaders, $2 \theta^{2} \sigma_{l}^{2}$, less twice the covariance due to the correlation in leaders, $\theta^{2} \sigma_{l}^{2} \rho$.

Under the null hypothesis that leaders do not matter, $\theta=0$. Therefore, under the null, the change in growth across a leader transition in country $i$ will be distributed:

$$
P \overline{O S T-P R} E_{z} \sim N\left(0,2 \frac{\sigma_{\varepsilon i}^{2}}{T}\right) .
$$

5. To simplify the exposition, assume for the moment that during each of these periods, there is only one leader. This assumption does not affect the statistical tests because, under the null that $\theta=0$, the variance as written in expression (2) would still be exactly correct even if there were multiple leaders in the pre- or postperiod. 
We can easily develop a Wald test statistic based on this null hypothesis. Define

$$
J=\frac{1}{Z} \sum_{i=1}^{Z} \frac{\left(P \widehat{O S T-P R} E_{i}\right)^{2}}{2 \widehat{\sigma_{\varepsilon i}^{2}} / T}
$$

where $\widehat{\sigma_{\varepsilon i}^{2}}$ is an estimate of $\sigma_{\varepsilon i}^{2}$ for country $i, P \widehat{O S T-P R E}_{i}$ represents the change in growth around a leader death in country $i$, and $Z$ is the number of leaders. If the number of observations of country $i$ is large, so that $\widehat{\sigma_{\varepsilon i}^{2}}$ is a good estimate for $\sigma_{\varepsilon i}^{2}$, then under the null $Z * J$ will be distributed $\chi^{2}(Z){ }^{6}$

The magnitude of $J$ is informative as well. Recalling equation (1) and rearranging terms,

$$
\theta^{2}=\frac{(J-1) \sigma_{\varepsilon}^{2}}{T \sigma_{l}^{2}(1-\rho)} .
$$

Normalizing $\sigma_{l}$ to 1 , setting $\rho=0$, and substituting in the variance of the error process, $\sigma_{\varepsilon}^{2}$, provides a conservative estimate of how much one standard deviation in leader quality affects growth. That is, we can estimate $\theta$, the magnitude of leader effects.

We also consider a general, nonparametric test that does not depend on assumptions about the structure of the growth process. ${ }^{7}$ This test simply asks whether the change in growth around a leader death is unusual given the changes in growth witnessed in that country at other years. We calculate the percentile rank of $P \overline{O S T-P R E}_{z}$ for each actual leader death date within the distribution of $P \overline{O S T-P R E}_{i t}$ for other years in that leader's country. This percentile rank, denoted $r_{z}$, will be uniformly distributed over the interval $[0,1]$ under the null hypothesis that leaders do not matter. Under the alternative hypothesis that leaders do matter, $r_{z}$ should be closer to extreme values-i.e., closer to 0 or 1 -than would be predicted by a uniform distribution.

We can therefore form a test-statistic that is the nonparametric analogue of the Wald test. To do so, first define $y_{z}=\left|r_{z}-1 / 2\right|$. Under

6. This exposition is based on simple iid errors. In the empirical work, we consider a more general error process that allows for heteroskedasticity and $\mathrm{AR}(1)$ autocorrelation when computing the $J$-statistic.

7. This test is a modification of the Rank test developed by Corrado [1989] in the context of the event study literature in finance. 
the null, $E\left[y_{z}\right]=1 / 4, \operatorname{var}\left[y_{z}\right]=1 / 48$, so that one can form the test-statistic:

$$
K=\frac{\Sigma\left(y_{z}-1 / 4\right)}{\sqrt{Z / 48}} .
$$

A nonparametric test for whether $\theta \neq 0$-i.e., whether the changes in $P \overline{O S T}-P R E_{z}$ at leader deaths are systematically larger than average-is a one-sided test of whether $K$ is systematically larger than is expected under the null. ${ }^{8}$

In the empirical work, we will also consider the possibility that there is heterogeneity in $\theta$ and $\rho$ across countries. The degree to which leaders can affect growth $(\theta)$ and the correlation of successive leaders $(\rho)$ may vary across institutional, historical, or social contexts, and we can examine this possibility by considering our empirical tests on subsets of leader deaths that share observable characteristics.

Note finally that, even if $\theta \neq 0$, the tests may still fail to reject the null. If successive leaders tend to be alike-because $\rho$ is close to 1 or $\sigma_{l}^{2}$ is close to 0 - then the tests will fail to reject even if leaders affect growth. Moreover, if the growth process in a country is extremely noisy, so that $\sigma_{\varepsilon i}^{2}$ is large, then it becomes more difficult to detect leader effects. A rejection of the null hypothesis therefore implies that leaders matter in three senses: (i) leaders impact outcomes, (ii) leaders vary enough that different leaders lead to different outcomes, and (iii) the impact of leader transitions is large relative to average events that occur in their countries.

\section{Do Leaders Matter? Evidence}

\section{IV.A. Leader Deaths}

This paper uses a data set on national leadership collected by the authors. The data set includes every postwar leader in every sovereign nation in the Penn World Tables [Heston, Summers, and Aten 2002] for which there are sufficient data to estimate

8. In large samples, the Central Limit Theorem implies that $K$ will be distributed under the null as $N(0,1)$. In practice, given the small number $(\leq 40)$ of growth observations in each country, the rank is distributed as a discrete uniform variable rather than a continuous uniform. This discreteness slightly increases the variance of $y_{z}$, and failing to account for this issue will lead to overrejection of the null. To be conservative, we therefore rely on Monte Carlo simulations to generate the exact distribution of $K$ under the null. 
leader effects-a total of 130 countries, covering essentially every nation today that existed prior to $1990 .{ }^{9}$ The resulting data set includes 1108 different national leaders, representing 1294 distinct leadership periods. ${ }^{10}$ More details about the leadership data set can be found in Jones and Olken [2004].

The leaders of particular interest for this paper are those who died in office, either by natural causes or by accident. To define this group, further biographical research was undertaken to determine how each leader came and went from power. Table I presents summary statistics describing the departure of leaders. Of the 105 leaders who died in office, 28 were assassinated, 65 died of natural causes, and 12 died in accidents. ${ }^{11}$ As discussed above, it is important for the identification strategy that the timing of these leader deaths be unrelated to underlying economic conditions. For this reason, it is important that assassinations, which may be motivated by underlying changes in the country, be purged from the set of leader deaths. We therefore define the 57 leaders who died either of natural causes or in accidents, and for whom we can estimate growth effects, as the "random" deaths that we focus on in the paper. ${ }^{12}$ Of these, heart disease is the most common cause of death, while cancer and air accidents were also relatively common. Table II describes each of these cases in further detail.

One question is whether the leaders we consider here are typical of leaders in power at any given time. To investigate this, in results not reported, we consider a Probit regression on all leaders-years in the entire data set, with the dependent variable a dummy distinguishing the 57 leaders in our sample. The independent variables in the regression are the leader's age and tenure, whether he was an autocrat (as classified by Polity IV), decade dummies, region dummies, and dummies for the country's per-capita income trecile in 1960 . The main finding is that, not

9. Leader data are collected from 1945 or the date of independence, whichever came later.

10. The data set is similar to one collected by Bienen and Van de Walle [1991], with the main exceptions that our data focus more closely on the nature of leadership transfer and extend to the year 2000, while their data include countries that are not covered by the Penn World Tables and extend further into the past.

11. A further 21 leaders, not counted here, were killed during coups.

12. Of the 77 leaders who died of natural causes or in accidents, sufficient Penn World Tables data to estimate the change in growth around the leader's death were available for 62 of them. As discussed in footnote 15 below, we exclude a further five leaders whose deaths were too close to the deaths of other leaders to separately estimate their impacts on growth. This yields the 57 leader deaths we focus on in the empirical analysis. 


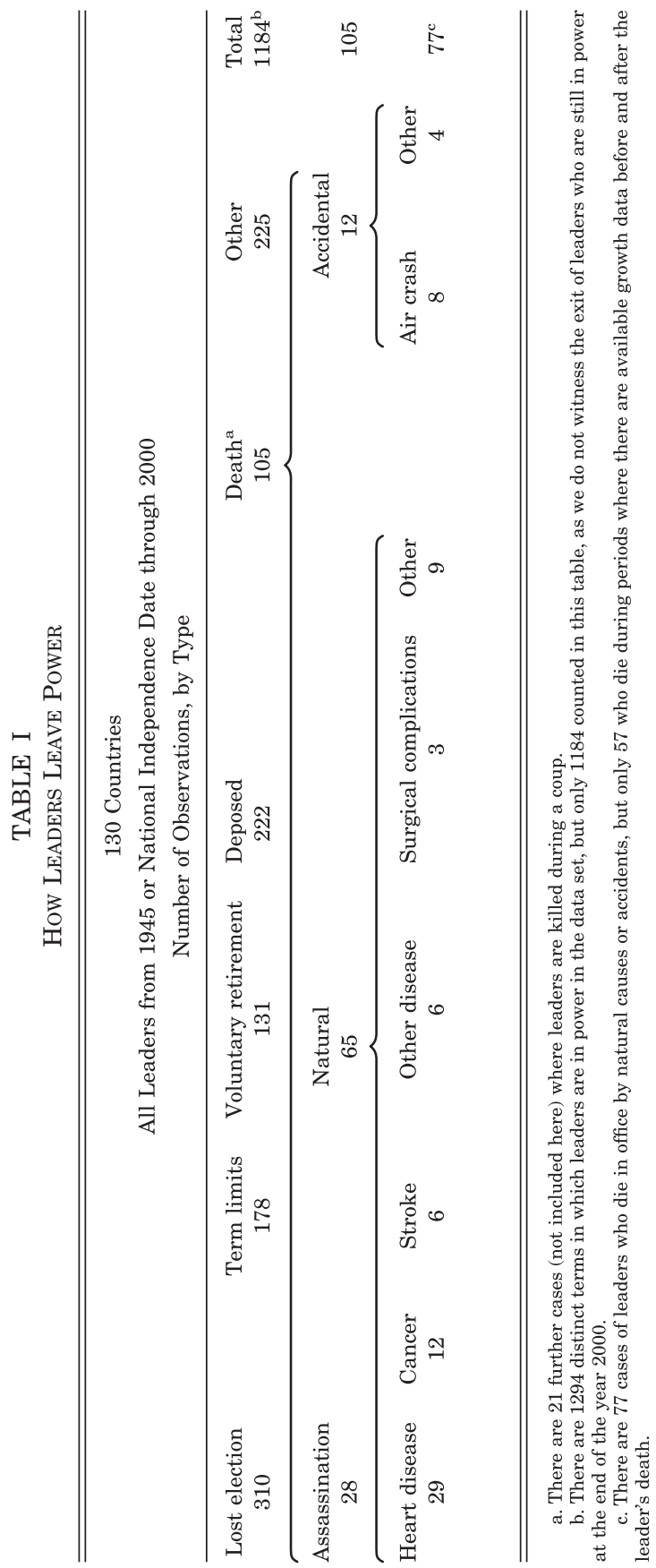


TABLE II

Deaths of National Leaders Due to Accidental or Natural Causes

\begin{tabular}{|c|c|c|c|c|}
\hline Country & Leader & $\begin{array}{c}\text { Year of } \\
\text { death }\end{array}$ & $\begin{array}{l}\text { Tenure } \\
\text { (years) }\end{array}$ & Nature of death \\
\hline Algeria & Houari Boumediene & 1978 & 13.5 & $\begin{array}{l}\text { Waldenstrom's disease } \\
\text { (blood disorder) }\end{array}$ \\
\hline Angola & Agostinho Neto & 1979 & 3.9 & $\begin{array}{l}\text { Cancer of the } \\
\text { pancreas }\end{array}$ \\
\hline Argentina & Juan Peron & 1974 & $.7^{\mathrm{a}}$ & $\begin{array}{l}\text { Heart and kidney } \\
\text { failure }\end{array}$ \\
\hline Australia & John Curtin & 1945 & 3.7 & Heart attack \\
\hline Australia & Harold Holt & 1967 & 1.9 & $\begin{array}{l}\text { Drowned while skin- } \\
\text { diving in Port } \\
\text { Philip Bay }\end{array}$ \\
\hline Barbados & John (Tom) Adams & 1985 & 8.5 & Heart attack \\
\hline Barbados & Errol Barrow & 1987 & $1.0^{\mathrm{a}}$ & $\begin{array}{l}\text { No cause of death } \\
\text { announced }\end{array}$ \\
\hline Bolivia & $\begin{array}{l}\text { Rene Barrientos } \\
\text { (Ortuna) }\end{array}$ & 1969 & $2.7^{\mathrm{a}}$ & Helicopter crash \\
\hline Botswana & Sir Seretse Khama & 1980 & 13.8 & Cancer of the stomach \\
\hline Brazil & Arthur da Costa e Silva & 1969 & 2.6 & $\begin{array}{l}\text { Paralytic stroke, then } \\
\text { heart attack }\end{array}$ \\
\hline China & Mao Tse-tung & 1976 & 26.9 & Parkinson's disease \\
\hline China & Deng Xiaoping & 1997 & 19.2 & Parkinson's disease \\
\hline Comoros & Prince Jaffar & 1975 & .4 & $\begin{array}{l}\text { While on pilgrimage } \\
\text { to Mecca }\end{array}$ \\
\hline Comoros & Mohamad Taki & 1998 & 2.7 & Heart attack \\
\hline Cote d'Ivoire & Felix Houphouet-Boigny & 1993 & 33.3 & $\begin{array}{l}\text { Following surgery for } \\
\text { prostate cancer }\end{array}$ \\
\hline Denmark & Hans Hedtoft & 1955 & $1.3^{\mathrm{a}}$ & $\begin{array}{l}\text { Heart attack in hotel } \\
\text { in Stockholm }\end{array}$ \\
\hline Denmark & Hans Hansen & 1960 & 5.0 & Cancer \\
\hline Dominica & Roosevelt Douglas & 2000 & 0.7 & Heart attack \\
\hline Ecuador & Jaime Roldos (Aguilera) & 1981 & 1.8 & Plane crash in Andes \\
\hline Egypt & Gamal Abdel Nasser & 1970 & 15.9 & Heart attack \\
\hline France & Georges Pompidou & 1974 & 4.8 & Cancer \\
\hline Gabon & Leon Mba & 1967 & 7.3 & Cancer (in Paris) \\
\hline Greece & Georgios II & 1947 & 11.4 & Heart attack \\
\hline Grenada & Herbert Blaize & 1989 & 5.0 & Prostate cancer \\
\hline Guinea & Sekou Toure & 1984 & 25.5 & $\begin{array}{l}\text { Heart attack during } \\
\text { surgery in Cleveland }\end{array}$ \\
\hline Guyana & Linden Burnham & 1985 & 19.2 & During surgery \\
\hline Guyana & Cheddi Jagan & 1997 & 4.4 & $\begin{array}{l}\text { Heart attack a few } \\
\text { weeks after heart } \\
\text { surgery }\end{array}$ \\
\hline Haiti & Francois Duvalier & 1971 & 13.5 & Heart disease \\
\hline Hungary & Jozsef Antall & 1993 & 3.6 & Lymphatic cancer \\
\hline Iceland & Bjarni Benediktsson & 1970 & 6.7 & House fire \\
\hline India & Jawaharlal Nehru & 1964 & 16.8 & Stroke \\
\hline India & Lal Bahadur Shastri & 1966 & 1.6 & Heart attack \\
\hline Iran & Ayatollah Khomeini & 1989 & 10.3 & $\begin{array}{l}\text { Following surgery to } \\
\text { stem intestinal } \\
\text { bleeding }\end{array}$ \\
\hline Israel & Levi Eshkol & 1969 & 5.7 & Heart attack \\
\hline
\end{tabular}


TABLE II

(CONTINUED)

\begin{tabular}{|c|c|c|c|c|}
\hline Country & Leader & $\begin{array}{c}\text { Year of } \\
\text { death }\end{array}$ & $\begin{array}{l}\text { Tenure } \\
\text { (years) }\end{array}$ & Nature of death \\
\hline Jamaica & Donald Sangster & 1967 & 0.1 & Stroke \\
\hline Japan & Masayoshi Ohira & 1980 & 1.5 & Heart attack \\
\hline Japan & Keizo Obuchi & 2000 & 1.7 & Stroke \\
\hline Jordan & Hussein al-Hashimi & 1999 & 46.5 & $\begin{array}{l}\text { Non-Hodgkin's } \\
\text { lymphoma }\end{array}$ \\
\hline Kenya & Jomo Kenyatta & 1978 & 14.7 & While sleeping \\
\hline Liberia & William V.S. Tubman & 1971 & 27.6 & $\begin{array}{l}\text { Complications } \\
\text { surrounding surgery } \\
\text { on prostate }\end{array}$ \\
\hline Luxembourg & Pierre Dupong & 1953 & 16.1 & $\begin{array}{l}\text { Complications from } \\
\text { broken leg }\end{array}$ \\
\hline Luxembourg & Pierre Frieden & 1959 & 0.9 & Cause unclear \\
\hline Malaysia & Tun Abdul Razak & 1976 & $5.3^{\mathrm{a}}$ & Leukemia (in London) \\
\hline Mauritania & Ahmed Ould Bouceif & 1979 & .1 & $\begin{array}{l}\text { Plane crash in } \\
\text { sandstorm over } \\
\text { Atlantic }\end{array}$ \\
\hline Morocco & Mohammed V & 1961 & $5.3^{\mathrm{a}}$ & $\begin{array}{l}\text { Following operation to } \\
\text { remove growth in } \\
\text { throat }\end{array}$ \\
\hline Morocco & Hassan II & 1999 & 38.4 & Heart attack \\
\hline Mozambique & Samora Machel & 1986 & 11.3 & $\begin{array}{l}\text { Plane crash near } \\
\text { Maputo }\end{array}$ \\
\hline Nepal & Tribhuvan & 1955 & 4.1 & Heart attack in Zurich \\
\hline Nepal & Mahendra & 1972 & 16.9 & Heart attack \\
\hline New Zealand & Norman Kirk & 1974 & 1.7 & Heart attack \\
\hline Nicaragua & Rene Schick Gutierrez & 1966 & 3.3 & Heart attack \\
\hline Niger & Seyni Kountche & 1987 & 13.6 & Cancer (brain tumor) \\
\hline Nigeria & Sani Abacha & 1998 & 4.6 & $\begin{array}{l}\text { Heart attack (some } \\
\text { say poisoned) }\end{array}$ \\
\hline Pakistan & Mohammed Ali Jinnah & 1948 & 1.1 & Heart failure \\
\hline Pakistan & Mohammed Zia Ul-Haq & 1988 & 11.1 & $\begin{array}{l}\text { Plane crash in } \\
\text { Pakistan }\end{array}$ \\
\hline Panama & $\begin{array}{l}\text { Domingo Diaz } \\
\text { Arosemena }\end{array}$ & 1949 & .9 & Heart attack \\
\hline Panama & Omar Torrijos Herrera & 1981 & 12.8 & $\begin{array}{l}\text { Plane crash near } \\
\text { Penonomé }\end{array}$ \\
\hline Philippines & Manuel Roxas y Acuna & 1948 & 1.9 & Heart attack \\
\hline Philippines & Ramon Magsaysay & 1957 & 3.2 & $\begin{array}{l}\text { Plane crash on Cebu } \\
\text { Island }\end{array}$ \\
\hline Poland & Boleslaw Bierut & 1956 & 11.2 & Heart attack \\
\hline Portugal & $\begin{array}{l}\text { Francisco de } \mathrm{Sa} \\
\quad \text { Carneiro }\end{array}$ & 1980 & 0.9 & $\begin{array}{l}\text { Light plane crash } \\
\text { near Lisbon }\end{array}$ \\
\hline Romania & $\begin{array}{l}\text { Gheorghe Gheorghiu- } \\
\text { Dej }\end{array}$ & 1965 & 17.2 & Pneumonia \\
\hline Sierra Leone & Sir Milton Margai & 1964 & 3.0 & After "brief illness" \\
\hline South Africa & Johannes G. Strijdom & 1958 & 3.7 & Heart disease \\
\hline Spain & Francisco Franco & 1975 & 36.3 & Heart failure \\
\hline Sri Lanka & $\begin{array}{l}\text { Don Stephen } \\
\text { Senanayake }\end{array}$ & 1952 & 4.5 & Thrown from horse \\
\hline Swaziland & Sobhuza II & 1982 & 60.7 & Unknown \\
\hline
\end{tabular}


TABLE II

(CONTINUED)

\begin{tabular}{|c|c|c|c|c|}
\hline Country & Leader & $\begin{array}{l}\text { Year of } \\
\text { death }\end{array}$ & $\begin{array}{l}\text { Tenure } \\
\text { (years) }\end{array}$ & Nature of death \\
\hline Sweden & Per Hansson & 1946 & 10.0 & Stroke \\
\hline Syria & Hafiz al-Assad & 2000 & 29.6 & Heart attack \\
\hline Taiwan & Chiang Kai-Shek & 1975 & $25.3^{\mathrm{a}}$ & Heart attack \\
\hline Taiwan & Chiang Ching-Kuo & 1988 & 12.8 & Heart attack \\
\hline Thailand & Sarit Thanarat & 1963 & 5.1 & $\begin{array}{l}\text { Heart and lung } \\
\text { ailments }\end{array}$ \\
\hline Trinidad and Tobago & Eric Williams & 1981 & 18.6 & $\begin{array}{l}\text { Complications from } \\
\text { diabetes }\end{array}$ \\
\hline United States & Franklin D. Roosevelt & 1945 & 12.1 & Stroke \\
\hline Uruguay & Tomas Berreta & 1947 & .4 & $\begin{array}{l}\text { During emergency } \\
\text { surgery }\end{array}$ \\
\hline Uruguay & Luis Ganattasio & 1965 & .9 & Heart attack \\
\hline Uruguay & Oscar Gestido & 1967 & .8 & Heart attack \\
\hline
\end{tabular}

a. Second time in power.

surprisingly, the leader's age positively predicts dying in office; in fact, leaders who die in office are eight years older than the typical leader in power at a given time. The other variables we consider are not jointly significant. ${ }^{13}$ Thus, with the prime exception of age, the leaders we consider here are broadly similar to the leaders occupying office throughout the period we consider.

Historical analysis of these leader deaths suggests many plausible cases in which leaders impact growth. Figure I highlights a few of the more dramatic examples, presenting the evolution of national income for four countries: China, Mozambique, Guinea, and Iran. In each graph, a solid vertical line indicates the exact date at which a leader died, and a dashed line indicates the date at which that leader came to power. In China, we see a remarkably close association between the long rule of Mao-from the period the data begin until his death in 1976-and a long period of poor growth. In fact, growth averages 1.7 percent per year under Mao but 5.9 percent per year subsequently. The forced collectivization of agriculture and the Cultural Revolution were among many national policies that likely served to retard growth during Mao's tenure, whereas Deng, who comes to power in 1978,

13. The only other variable to be individually significant in the regression is the leader's tenure-conditional on the leader's age, longer tenure makes you less likely to die. 


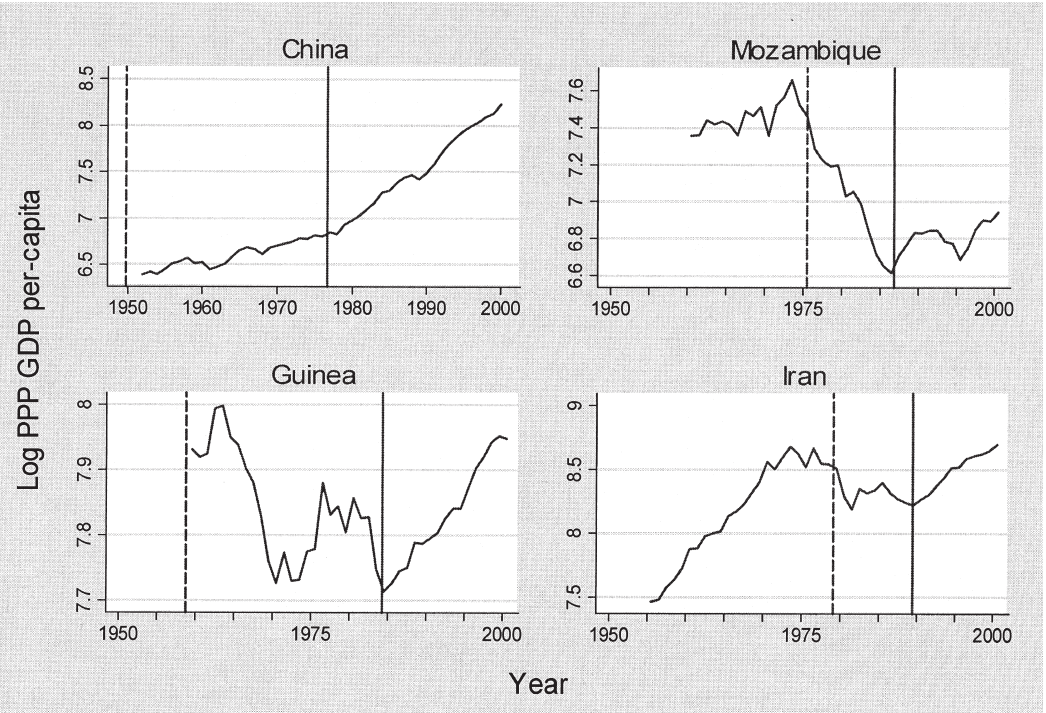

Figure I

Growth and Leader Deaths

is often regarded as having moved China toward more marketoriented policies.

The death of Samora Machel in Mozambique was followed by an especially sharp turnaround in economic performance. Machel, the leader of the Frelimo guerrilla movement, established a one-party communist state and nationalized all private land upon becoming president of Mozambique in 1975. Coincident with Machel's policies, most Portuguese settlers fled Mozambique, and a new guerrilla insurgency was born. After Machel's death, Mozambique moved firmly under his successor, Joaquin Chissano, toward free-market policies, multiparty democracy, and peace with the insurgents. During Machel's eleven-year rule, growth was persistently negative, averaging -7.7 percent per year; since Machel's death, growth in Mozambique has averaged 2.4 percent per year.

Guinea and Iran provide further examples. In Guinea the rule of Sekou Toure was characterized by totalitarianism, paranoia, and violent purges until he died during emergency heart surgery in 1984. In Iran the rule of Ayatollah Khomeini was marked by bloody conflict in both the Iranian Revolution and the Iran-Iraq war. Khomeini cast the Iran-Iraq war in strictly reli- 
gious terms, which is said to have prevented peace negotiations for many years. As can be seen in Figure I, both Guinea and Iran experienced dramatic growth reversals coincident with the death of these leaders.

Of course, the associations between particular leaders and particular growth episodes may be coincidental, and among the 57 leader deaths in our sample there are many cases where growth does not appear to change. In the next sections we leave historical argument aside and pursue the question of whether leaders matter for economic growth using more rigorous econometric methods.

\section{IV.B. Results}

To implement the econometric tests developed in Section III, we estimate the following regression:

$$
g_{i t}=\alpha_{z} P R E_{z}+\beta_{z} P O S T_{z}+v_{i}+v_{t}+\varepsilon_{i t},
$$

where $g_{i t}$ is the annual growth rate of real purchasing-powerparity GDP per capita taken from the Penn World Tables, $i$ indexes countries, $t$ indexes time in years, and $z$ indexes leader deaths. Country and time fixed effects are included through $v_{i}$ and $v_{t}$, respectively. For each leader death, indexed by $z$, there is a separate set of dummies, denoted $P R E_{z}$ and $P O S T_{z} . P R E_{z}$ is a dummy equal to 1 in the $T$ years prior to leader $z$ 's death in that leader's country. POST $z$ is a dummy equal to 1 in the $T$ years after leader $z$ 's death in that leader's country. We estimate a separate coefficient $\alpha_{z}$ and $\beta_{z}$ for each leader death $z$. Note that we estimate equation (5) using all countries and all years of data, as countries without leader deaths can be used to help estimate time fixed effects.

In the main analysis, we let the period of observation $T$ be five years, though results are similar when we let $T$ be either three or seven years. Note also that $P R E_{z}$ and $P O S T_{z}$ are defined so that the actual year of the death is not included in either dummy. This is probably the most conservative strategy when looking for longer-term leader effects, as it helps to exclude any immediate turbulence caused by the fact of leader transition itself. $^{14}$

14. The results in this paper are robust to a number of other methods of handling transition years. For example, assigning the transition year to either the $P R E$ or POST dummy, or assigning a fraction of the dummy to either the PRE or 
TABLE III

Do LEADERS MATTER?

\begin{tabular}{|c|c|c|c|c|c|c|}
\hline & \multicolumn{3}{|c|}{ All leaders } & \multicolumn{3}{|c|}{$\begin{array}{l}\text { Leaders with tenure } \\
\quad \geq 2 \text { years }\end{array}$} \\
\hline & $\begin{array}{c}J- \\
\text { statistic }\end{array}$ & $\begin{array}{c}\text { Wald } \\
P \text {-value }\end{array}$ & $\begin{array}{c}\text { Rank } \\
P \text {-value }\end{array}$ & $\begin{array}{c}J- \\
\text { statistic }\end{array}$ & $\begin{array}{c}\text { Wald } \\
P \text {-value }\end{array}$ & $\begin{array}{c}\text { Rank } \\
P \text {-value }\end{array}$ \\
\hline \multicolumn{7}{|l|}{ Treatment timings } \\
\hline$t$ & 1.312 & $.0573^{*}$ & $0.017 * *$ & 1.392 & $.0390 * *$ & $0.004 * * *$ \\
\hline$t+1$ & 1.272 & $.0845^{*}$ & $0.075^{*}$ & 1.361 & $.0537^{*}$ & $0.052 *$ \\
\hline$t+2$ & 1.308 & $.0669^{*}$ & 0.172 & 1.443 & $.0314^{* *}$ & 0.121 \\
\hline \multicolumn{7}{|l|}{ Control timings } \\
\hline$t-5$ & 0.841 & .7953 & 0.446 & 0.918 & .6269 & 0.357 \\
\hline$t-6$ & 0.986 & .5026 & 0.806 & 0.962 & .5409 & 0.905 \\
\hline Number of leaders $(t)$ & 57 & 57 & 57 & 47 & 47 & 47 \\
\hline $\begin{array}{l}\text { Number of } \\
\text { observations }(t)\end{array}$ & 5567 & 5567 & 5567 & 5567 & 5567 & 5567 \\
\hline
\end{tabular}

Under the null hypothesis, growth is similar before and after randomly timed leader transitions. $P$-values indicate the probability that the null hypothesis is true. The $J$-statistic is the test statistic described in equation (3) in the text: under the null, $J=1$, and higher values of $J$ correspond to greater likelihood that the null is false. $P$-values in columns 2 and 5 are from Chi-squared tests, where the POST and $P R E$ dummies are estimated via OLS allowing for region-specific heteroskedasticity and a region-specific AR(1) process, where the regions are Asia, Latin America, Western Europe, Eastern Europe/Transition, Middle East/North Africa, Sub-Saharan Africa, and Other. Estimation using alternative error structures for the Wald test produce similar or stronger results. Estimation of columns 3 and 6 is via the Rank-method described in the text. The regressions reported in this table compare five-year growth averages before and after leader deaths. The treatment timing " $t$ " considers growth in the five-year period prior to the transition year with growth in the five-year period after the transition year. The treatment timings " $t+1$ " and " $t+2$ " shift the POST period forward one and two years, respectively. The control timings shift both PRE and POST dummies five and six years backward in time. Significance at the 10 percent, 5 percent, and 1 percent level is denoted by $*, * *$, and $* * *$, respectively.

Table III presents the main results from the formal econometric tests developed in Section III. Column 1 presents the $J$-statistic defined in Section III, with the errors corrected for region-specific heteroskedasticity and a region-specific AR(1) process. Column 2 presents the $p$-value on the $J$-statistic. Column 3 presents the $p$ value from the analogous nonparametric Rank test. Columns 4-6 repeat this analysis, restricting the set of leaders to those who were in office for at least two years prior to their death, whose effect on growth we would expect to be stronger.

For each specification of the error structure, we present three different timings of the PRE and POST dummies. The actual timing is represented by the row labeled $t$. To ensure that the effects we ascribe to leaders are not simply caused by temporary

POST dummy, produces similar or slightly stronger results than those presented here. 
changes during the transition period, the timings $t+1$ and $t+2$ are included, indicating that the POST dummies have been shifted one and two years later in time. Put another way, in the $t+1$ timing, we exclude the year of the transition and the subsequent year from the analysis; in the $t+2$ timing, we exclude the year of the transition and the two subsequent years from the analysis. ${ }^{15}$

The results presented in Table III show that leaders have significant effects on growth. Using the contemporaneous leader timing $(t)$, both the Wald and the Rank tests reject the null hypothesis that leaders do not matter. Results are also generally strong when we shift the POST timing forward one or two years, suggesting that the effect of leaders is not due to temporary effects of the transition. If we restrict the data to rule out leader deaths where the leader was in power for a very short period of time, then the results become stronger, despite having ten fewer deaths in the sample.

The magnitudes of the estimated leader effects are substantial. For all leaders, the $J$-statistic is 1.312 , so the variance of the coefficients on POST-PRE is 31 percent higher around leader transitions than it would be normally. Recalling equation (4), which relates $J$ to $\theta$, normalizing the standard deviation of leader quality to 1 , and substituting for the standard deviation in growth in these countries (0.060) yields an estimate of theta of 0.0147. ${ }^{16}$ This means that a one standard deviation increase in leader quality increases growth rates by at least 1.47 percentage points per year-which is a quite dramatic effect.

Even though growth changes when leaders die, it does not appear to systematically increase or decrease; in fact, the average value of the coefficients on POST-PRE is -0.10 percentage points-i.e., almost exactly 0 . However, if certain characteristics of a leader predicted the leader's quality, then the change in growth following a leader's death might be related to certain

15. Note that we exclude five leader deaths (Barrow of Barbados, Hedtoft of Denmark, Shastri of India, Frieden of Luxembourg, and Gestido in Uruguay), because their deaths followed closely on a prior leader death in their countries. Including both leaders would cause the $P R E$ and POST dummies to overlap, contaminating the results. In each case, we drop the leader who died second, though the results are robust to dropping the leader who died first instead.

16. This estimate assumes that $\rho$, the correlation between leaders, is 0 ; i.e., each leader is an independent draw from the potential leader quality distribution. Assuming that leaders were perfectly inversely correlated $(\rho=-1)$ implies a lower-bound value of $\theta$ of 0.0104 , so that a one standard deviation in leader quality changes annual growth rates by 1 percentage point. If, as seems more likely, the quality of successive leaders is positively correlated, then $\theta$ would be even higher than the 0.0147 reported in the text. 
characteristics of the outgoing leader. For example, Lord Acton's famous observation that "power tends to corrupt; absolute power corrupts absolutely" suggests declining performance over a leader's tenure, while work by Clague et al. [1996] finds that property and contract rights actually tend to improve the longer an autocrat has been in power. Other researchers suggest that expectations of longer tenure can lead to longer planning horizons and greater expectations of stability by the leader and the public at large, potentially enhancing investment [Blondel 1987; Olson 1993, 2000]. In results not reported here, however, we find that neither the leader's age nor tenure in office predicts the change in growth following the leader's death, either directly or when interacted with the autocracy measure discussed below.

\section{IV.C. Specification Checks}

These tests survive a wide range of robustness and specification checks. First, the final rows of Table III present $p$-values for "control timings," where the PRE and POST dummies are shifted five or six years backwards in time. If the identification strategy is valid and the growth process is correctly specified, one should not witness unusual changes in growth at these timings. In fact, we find that such control timings fail to reject the null, further confirming both the identification assumption and the specification of the error structure used in forming the Wald tests.

We can further test the underlying identification assumption-that leader deaths are exogenously timed with respect to underlying economic conditions-by attempting to predict the deaths using economic information. In particular, we estimate a conditional fixed-effects logit model, where the independent variables are lags of growth and other economic variables and the dependent variable is a dummy variable equal to one in the year of a leader death. As shown in Table IV, we find that the key variable of interest_-growth-as well as changes in the components of GDP and changes in the terms of trade, do not predict these leader transitions. The one variable that has predictive power is the nominal exchange rate, which is unusually steady prior to leader deaths. This result turns out to be driven by outliers in other years of observation, i.e., episodes of massive exchange rate adjustments, which do not occur in the years prior to the leader deaths. Such rare episodes substantially affect the mean shift in exchange rates in the background years, and if we drop the outliers (i.e., devaluations of more than 25 percent in a 
TABLE IV

Do Economic Variables Predict Leader Deaths?

(1)

Growth

Change in consumption

Change in government expenditure

Change in investment

Previous year's

(1.553)

$-0.127$

(1.109)

0.802

$(0.692)$

Change in trade

Change in terms of trade

Change in exchange rate

Observations

2267

2265

Reported coefficients are from a conditional fixed-effects logit model of the probability of a leader death occurring in a given year, conditional on the number of leader deaths that actually occurred in each country. Results using mean changes in the independent variables over the previous three or five years, rather than in the previous year, are qualitatively similar. Standard errors are in parentheses. Significance at the 10 percent, 5 percent, and 1 percent level is denoted by *,**, and ***, respectively.

single year), then more normal exchange rate movements have no predictive power for leader deaths.

The main results in Table III are also robust to a number of further specification checks, including three- or seven-year observation windows $(\mathrm{T})$, different sets of right-hand-side control variables, and the exclusion of certain decades or types of deaths. ${ }^{17}$

\section{How Do Country Level Characteristics INTERACT WITH LEADERS?}

The above results indicate that, on average, leaders have detectable, causative impacts on national growth. However, the

17. Specifically, we reestimate equation (5) without any time fixed effects, allowing for time fixed effects that are allowed to vary by region, and including lagged income plus a host of plausibly exogenous control variables. We also estimate leader effects separately excluding heart attacks and air crashes, the two types of death most frequently plagued by conspiracy theories. Finally, to ensure that no decade is driving the results, we rerun the results excluding each decade one-byone. The results are broadly robust to all of these alternative specifications. 
TABLE V

Interactions with Type of Political Regime in Year Prior to Death

\begin{tabular}{lcccccc}
\hline \hline & $\begin{array}{c}J- \\
\text { statistic }\end{array}$ & $\begin{array}{c}\text { Wald } \\
P \text {-value }\end{array}$ & $\begin{array}{c}\text { Rank } \\
P \text {-value }\end{array}$ & $\begin{array}{c}J \text { - } \\
\text { statistic }\end{array}$ & $\begin{array}{c}\text { Wald } \\
P \text {-value }\end{array}$ & $\begin{array}{c}\text { Rank } \\
P \text {-value }\end{array}$ \\
\hline \multicolumn{3}{c}{ Autocrats (Polity IV) } & Democrats (Polity IV) \\
$t r$ Treatment timings & & & & & & \\
$t+1$ & 1.621 & $0.019^{* *}$ & $0.040^{* *}$ & 1.000 & 0.460 & 0.106 \\
$t+2$ & 1.672 & $0.016^{* *}$ & $0.017^{* *}$ & 0.932 & 0.552 & 0.712 \\
Control timings & 1.592 & $0.028^{* *}$ & $0.051^{*}$ & 1.021 & 0.432 & 0.636 \\
$t-5$ & & & & & & \\
$t-6$ & 0.849 & 0.698 & 0.837 & 0.866 & 0.632 & $0.075^{*}$ \\
Number of leaders $(t)$ & 1.094 & 0.334 & 0.977 & 0.647 & 0.873 & 0.191 \\
\hline \hline
\end{tabular}

See notes to Table III. Distinctions across leader sets are defined using the "polity" variable in the Polity IV data set in the year prior to the leader's death. Autocrats are defined by having a polity score less than or equal to 0 . Democrats are those leaders with a polity score greater than 0 .

degree to which leaders matter may well be a function of their context, as different institutional systems might amplify or retard a leader's influence. We therefore extend the regression framework above to consider hypothesis tests on subsets of the leader deaths, in order to examine the interaction of various national characteristics with the ability of leaders to influence growth.

The primary measure of institutional constraints we use is the "polity" variable from the Polity IV data set, which provides annual panel data on institutional characteristics [Marshall and Jaggers 2000]. ${ }^{18}$ The results are presented in Table V, which compares those leaders whose nations receive a polity score less than or equal to zero in the year prior to their death, who we will refer to as "autocrats," with those leaders whose nations receive a polity score better than zero, who we will refer to as "democrats." The results indicate that autocratic leaders on average have a significant causative influence on national growth. In particular, the autocratic leader effects are strongly significant at treatment timings of $t, t+1$, and $t+2$, suggesting that the growth effects last over substantial periods and are not due to immediate turbulence in the first two years after the transition. In fact, the data

18. We focus on Polity IV ratings because they are available for the entire period we study. Other sources of institutional classification, such as Przeworski et al. [2000] and Freedom House [Karatnycky, Piano, and Puddington 2003], have generally similar classifications for the periods where they overlap with Polity. 
suggest that growth tends to increase slightly following the death of autocrats, not decline, providing further evidence that the effect of autocrat deaths is not due to turbulence. ${ }^{19}$ The magnitudes of the autocrat effects are substantial; using calculations analogous to those above, the $J$-statistic of 1.621 for autocrats implies an estimated value of $\theta$ of 2.1 ; i.e., a one standard deviation in leader quality increases growth by 2.1 percentage points per year. On the other hand, the deaths of leaders in democratic regimes produce no detectable impact on growth. ${ }^{20}$

Of course, autocracy versus democracy is a crude measure, and there are several reasons why autocrats might have more of an effect than democrats. The role of leaders in democracies differs from that in autocracies in the constraints placed on the leader's power, in how leaders are selected, and in the ease with which bad leaders are removed from power, among other things. Distinguishing between these different factors is difficult, both because they are hard to measure and because they tend to move hand-in-hand with one another.

Nevertheless, it is possible to obtain suggestive evidence regarding these factors. Table VI shows that, among autocrats, we also find particularly strong leader effects in regimes without political parties, and no effects where there are political parties. (For brevity, we present only the Rank-based $p$-values in this table, though the Wald-based results are generally similar except where noted.) Similarly, in results not presented, we find that leader effects are much stronger among those autocrats without a legislature, where presumably there are few constraints on their power, than among autocrats whose regime also includes a legislature. In terms of how leaders are selected, Table VI compares those autocrats who initially seized power in some type of coup d'etat with those autocrats who came to power though some other means (either by being elected or by being selected by the previous leader or ruling party). The results are much less conclusive,

19. On average, the change in annual growth rates following the leaders' death (i.e., the coefficients on POST - PRE) is +0.4 percentage points for autocrats and -0.5 percentage points for democrats, though the difference between the two is not statistically significant.

20. The differences between autocrats and democrats are also found when we use the smaller data sets for which the Przeworski et al. [2000] and the Freedom House measures are available. The only change is that we can now also find some statistically significant effects of democrats with the Przeworski et al. measure of democrats and with the Freedom House measure of "Free," although they are significant only using the Rank test and only then at $t=0$, while all other timings and many specifications of the Wald test show no democrat effects. 
TABLE VI

INTERACTIONS WITH COUNTRY CHARACTERISTICS

$P$-values: Probability that dependent variable does not change systematically across randomly timed leader deaths

\begin{tabular}{|c|c|c|c|}
\hline \multicolumn{2}{|c|}{$\begin{array}{c}\text { Presence of political } \\
\text { parties (autocracies only) }\end{array}$} & \multicolumn{2}{|c|}{$\begin{array}{l}\text { Selection of leader } \\
\text { (autocracies only) }\end{array}$} \\
\hline $\begin{array}{l}\text { No political } \\
\text { parties }\end{array}$ & $\begin{array}{l}\text { Has political } \\
\text { parties }\end{array}$ & Seized power & $\begin{array}{l}\text { Did not seize } \\
\text { power }\end{array}$ \\
\hline
\end{tabular}

Treatment timings $t$ $t+1$
$t+2$ $0.001 * * *$ 0.602 0.118 0.152 $0.002 * * *$ 0.280 $0.040^{* *}$ 0.210

Number of leaders $(t)$

$0.010^{* * *}$ 9
0.133

0.272

15

13 13

$\begin{array}{ccc}\text { Low income } & \text { Middle income } & \text { High income } \\ \text { in } 1960 & \text { in } 1960 & \text { in } 1960\end{array}$

All AutocDemoc All AutocDemoc All Autoc Democ

Treatment timings

$t+1$

$t+2$

$0.2640 .2230 .4510 .096 * 0.072 * 0.5310 .042 * * 0.067 * 0.082 *$

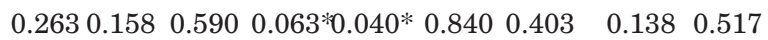

Number of leaders $(t)$

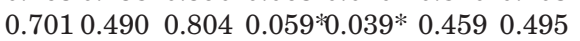

0.1110 .638

\begin{tabular}{lllllllll}
15 & 11 & 3 & 24 & 17 & 5 & 15 & 1 & 12 \\
\hline
\end{tabular}

High ethnic

fragmentation

\begin{tabular}{llllll}
\cline { 5 - 6 } All Autoc & Democ & All Autoc & Democ \\
\hline
\end{tabular}

Treatment timings

$t+1$

$t+2$

$0.029 * *$

$0.034^{* *}$

0.371

$0.091^{*}$

0.157

0.113

0.133

0.137

0.493

0.253

$0.010^{* * * *}$

0.750

Number of leaders $(t)$

0.375

0.608

0.193

$0.004^{* * * *}$

0.702

28

18

$\begin{array}{ll}10 & 22\end{array}$

8

10

See notes to previous tables. "Presence of political parties" is based on the "mobilize" variable from Przeworski et al. [2000], and "Selection of Leader" is from authors' classification. "High" ethnic fragmentation refers to all countries above the median in that variable among all countries in the sample, not just countries with random leader deaths. Low income, middle income, and high income split countries into thirds by per-capita income in 1960 . The table reports $p$-values for the Rank test of the null hypothesis that growth does not change unusually in the five years before and after a random leadership transition.

but suggest somewhat stronger leader effects among leaders who seize power than among other leaders. This difference is much more pronounced using the Wald-based tests, which show sub- 
stantial effects among leaders who seize power and no effects otherwise. Overall, these results provide further and more textured support for the Weberian hypothesis that leaders matter when institutions are weak.

An alternative hypothesis for the distinction between autocrats and democrats is that income, rather than institutions per se, drives the observed difference in leader effects. The second panel of Table VI explores this hypothesis, and shows that leader effects are not simply a matter of poverty. Indeed, the poorest countries show no leader effects on average, while both middle income and rich countries show significant effects. Meanwhile, the distinction between autocrats and democrats continues to operate, particularly within the middle income countries. Increasingly small sample sizes preclude conclusive interpretations, but one may speculate that the absence of autocrat effects among the poorest countries may be related to weaker state institutions and failed states, which may limit a leader's ability to influence national outcomes.

Table VI also explores the effect of ethnic fragmentation on leader effects. Previous work has shown that ethnic fragmentation is a strong negative predictor of growth [Easterly and Levine 1997; Alesina et al. 2002] and helps predict institutional quality, including measures for the quality of government [La Porta et al. 1999] and corruption [Mauro 1995], although other authors note that ethnic identity itself may be endogenous with respect to political variables (e.g., Posner [2003]). With regard to national leadership, ethnically fragmented nations may provide particular opportunities for leaders to impact national outcomes by choosing to foment or suppress ethnic conflict. We divide countries into high and low ethnic fragmentation groups depending on whether they fall above or below the median level of the ethno-linguistic fractionalization measure from Easterly and Levine [1997] and then subdivide them according to whether the leader was an autocrat or a democrat. We find that, overall, the autocrat/democrat distinction seems more important than the distinction by ethnic fragmentation.

\section{What Policies Do Leaders Affect?}

So far, this paper has focused on growth as the outcome of interest. But leaders may affect a number of economic policy variables as well as growth. This section examines whether lead- 
TABLE VII

What Policies Do Leaders AfFect?

$P$-values: Probability that dependent variable does not change systematically across randomly timed leader deaths

\begin{tabular}{llcl}
\hline Growth of & & \\
Inflation & $\begin{array}{l}\text { government } \\
\text { expenditure }\end{array}$ & $\begin{array}{c}\text { Growth of } \\
\text { trade }\end{array} \quad$ Any conflict \\
\hline
\end{tabular}

\begin{tabular}{lcccc}
\cline { 2 - 5 } All leaders & & & & \\
$t+1$ & $0.006^{* * *}$ & 0.200 & 0.284 & 0.715 \\
$t+2$ & $0.036^{* *}$ & 0.114 & 0.195 & 0.589 \\
Autocrats & $0.065^{*}$ & 0.178 & 0.164 & 0.482 \\
$t$ & & & & \\
$t+1$ & $0.009^{* * *}$ & 0.356 & 0.251 & 0.471 \\
$t+2$ & $0.039^{* *}$ & 0.492 & 0.162 & 0.39 \\
Democrats & $0.025^{* *}$ & 0.300 & $0.057^{*}$ & 0.303 \\
$t$ & & & & \\
$t+1$ & 0.186 & 0.202 & 0.492 & 0.789 \\
$t+2$ & 0.207 & $0.088^{*}$ & 0.445 & 0.717 \\
Number of leaders $(t)$ & 0.158 & 0.327 & 0.682 & 0.701 \\
\hline \hline
\end{tabular}

See notes to previous tables. Dependent variables are described in the text.

ers have an impact on four types of policy outcomes; monetary policy, fiscal policy, trade policy, and security policy. To do this, we apply the same techniques developed above to a host of different policy variables. ${ }^{21}$

To investigate whether leaders affect monetary policy, we examined whether there were significant changes in the inflation rate following the deaths of leaders. We use the annual change in the log GDP deflator from the Penn World Tables as our main measure of inflation. We then examine whether each of these variables changes systematically around leader deaths. The results, presented in Table VII, show substantial evidence of changes in inflation rates following the death of autocrats, although not following the death of democrats. In results not re-

21. Many of the variables in this section, unlike growth, are highly serially correlated, and some (particularly the monetary variables) may follow GARCH processes, so in this section we focus on the Rank test, which is robust to these alternative error structures. 
ported, we also found significant changes in the broad money supply (M2), especially for autocrats, though we found no detectable movements in M1. We find only weak evidence of changes in real exchange rates, and no evidence of changes in the black market premium associated with leader deaths.

The fact that leaders appear to be affecting monetary policy is consistent with the work of Romer and Romer [2003], who found that different Federal Reserve chairs are associated with different monetary policies and different macroeconomic outcomes. The results here suggest that, particularly for countries with strong leaders and, presumably, less independent central banks, it may be the views of the national leader that are critical in determining monetary policy.

To examine the impact of leaders on fiscal policy, we examine data from the Penn World Tables on the growth rate of government consumption in the national accounts. The results here are mixed. The results based on the Rank-test, presented in Table VII, show at best weak evidence for changes in fiscal policy surrounding the death of leaders. Wald tests (not presented) meanwhile suggest substantial and statistically significant changes in the growth rate of government expenditures, particularly following the death of autocrats. Unfortunately, more detailed annual panel data on other variables of interest, such as tax revenues and central government debt, were not available for most of the observations in our sample, and analysis of these other variables in the subsamples do not produce robust results. Therefore, while we cannot rule out fiscal policy changes, we conclude that there is no strong evidence of such effects.

We also examine whether there were changes in the growth rate of international trade. While the results presented in Table VII show no statistically significant overall changes in the growth of trade, the results may suggest an effect for autocrats, particularly when the POST dummy is shifted several years into the future. To look more directly at trade policy, we also examined data on average tariff rates, using data from the World Development Indicators. Unfortunately, data on tariffs were only available for 16 of the 57 leader deaths, and we found no statistically significant effects on tariff rates for those leaders.

Finally, we examine changes in security policy by looking at measures of conflict. We use annual conflict data from the PRIO/ Uppsala Armed Conflict Dataset [Gleditsch et al. 2002]. The conflict variable takes a value of 0 if there is no conflict, 1 if there 
is a minor armed conflict, 2 if there is an intermediate armed conflict, and 3 if there is a major armed conflict. ${ }^{22}$ The results in Table VII show no unusual changes in conflict associated with leader deaths. In results not reported, we also tried splitting the sample based on whether the country was in conflict or not in the year before the leader's death, and using discrete models such as probit or multinomial logit to examine the change in conflict status, and also to restricting the variable to look only at internal conflicts. None of these procedures found any unusual changes in conflict following the death of leaders.

The results therefore provide strong evidence that leaders affect monetary policy but no persuasive evidence that leaders affect fiscal, trade, or security policy. Of course, the set of panel data variables with coverage of the entire period is somewhat limited, so it is possible that, using more detailed data or a larger sample of leaders, we would find more effects.

\section{CONCLUSION}

Recent work in the cross-country growth literature has suggested that growth in the typical country changes dramatically from one decade to the next, with developing countries in particular showing sharp changes in growth patterns. This paper considers one possible force-the national leader-in explaining these growth experiences. Exogenously timed leader transitions are used as a natural experiment to identify the causative impact of leaders.

We find that countries experience persistent changes in growth rates across these leadership transitions, suggesting that leaders have a large causative influence on the economic outcomes of their nations. The paper further shows that the effects of leaders are very strong in autocratic settings but much less so in the presence of democratic institutions.

These results add texture to a growing literature on institutions in shaping economic outcomes. In particular, this paper suggests that while political institutions may matter, their impact is not deterministic. Rather, one important effect of political institutions is to constrain the power of individual leaders. De-

22. Minor conflict is defined to be at least 25 deaths per year but no more than 1000 total deaths over entire conflict history; intermediate is defined to be between 25 and 1000 deaths per year and more than 1000 total deaths in conflict history; major is defined to be more than 1000 deaths per year. 
mocracies may be able to prevent the disastrous economic policies of Robert Mugabe in Zimbabwe or Samora Machel in Mozambique; however, they might also have constrained the successful economic policies of Lee-Kwan Yew in Singapore or Deng Xiaoping in China.

The authors' primary interest in this study is to improve our understanding of the forces behind economic outcomes. However, this research also informs a separate and very old literature in history and political science that considers the role of national leaders in shaping events. Deterministic views suggest that leaders have little or no influence, while the Great Man view of history, at the other extreme, sees history as the biographies of a small number of individuals. Tolstoy believed this debate methodologically impossible to settle [Tolstoy 1869]. Using exogenously timed leader deaths, the analysis in this paper presents a methodology for analyzing the causative impact of leaders. We reject the hypothesis that leaders are incidental. We find that leaders do matter, and they matter to something as significant as national economic growth.

Northwestern University and National Bureau of Economic Research National Bureau of Economic Research

\section{REFERENCES}

Acemoglu, Daron, Simon Johnson, and James Robinson, "The Colonial Origins of Comparative Development: An Empirical Investigation," American Economic Review, XCI (2001), 1369-1401.

Alesina, Alberto, Arnaud Devleeschäuwer, William Easterly, Sergio Kurlat, and Roman Wacziarg, "Fractionalization," Journal of Economic Growth, VIII (2002), 155-194.

Berlin, Isaiah, Russian Thinkers (London: Hogarth Press, 1978).

Bertrand, Marianne, and Antoinette Schoar, "Managing with Style: The Effect of Managers on Firm Policies," Quarterly Journal of Economics, CXVIII (2003), 1169-1208.

Bienen, Henry, and Nicolas Van de Walle, Of Time and Power (Stanford, CA: Stanford University Press, 1991).

Blondel, Jean, Political Leadership (London: Sage Publications, 1987).

Butterfield, Herbert, The Whig Interpretation of History (London: G. Bell and Sons, 1931).

Carlyle, Thomas, The French Revolution: A History (London: Chapman and Hall, 1837).

, On Heroes, Hero Worship and the Heroic in History (New York: Wiley and Halsted, 1859).

Clague, Christopher, Philip Keefer, Stephen Knack, and Mancur Olson, "Property and Contract Rights under Democracy and Dictatorship," Journal of Economic Growth, I (1996), 243-276.

Corrado, Charles J., "A Nonparametric Test for Abnormal Security-Price Performance in Event Studies," Journal of Financial Economics, XXIII (1989), $385-395$. 
Downs, Anthony, An Economic Theory of Democracy (New York: Harper and Row, 1957).

Duflo, Esther, and Raghabendra Chattopadhyay, "Women as Policy Makers: Evidence from a Randomized Policy Experiment in India," Econometrica, LXXII (2004), 1409-1443.

Easterly, William, and Ross Levine, “Africa's Growth Tragedy: Policies and Ethnic Divisions,” Quarterly Journal of Economics, CXII (1997), 1203-1250.

Easterly, William, Michael Kremer, Lant Pritchett, and Lawrence H. Sümmers, "Good Policy or Good Luck? Country Growth Performance and Temporary Shocks," Journal of Monetary Economics, XXXII (1993), 459-483.

Fair, Ray C., "The Effect of Economics Events on Votes for President," Review of Economics and Statistics, LX (1978), 159-173.

Frankel, Benjamin, ed., The Cold War: 1945-1991 (Detroit, MI: Gale Research, 1992).

Gemmill, Gary, and Judith Oakley, "Leadership: An Alienating Social Myth?" Human Relations, XLV (1992), 113-129.

Glaeser, Edward L., Rafael La Porta, Florencio Lopez-de-Silanes, and Andrei Shleifer, "Do Institutions Cause Growth?" Journal of Economic Growth, IX (2004), 271-303.

Gleditsch, Nils P., Peter Wallensteen, Mikael Eriksson, Margareta Sollenberg, and Harvard Strand, "Armed Conflict 1946-2001: A New Dataset," Journal of Peace Research, XXXIX (2002), 615-637.

Hall, Robert E. and Charles I. Jones, "Why Do Some Countries Produce So Much More Output per Worker Than Others?" Quarterly Journal of Economics, CXIV (1999), 83-116.

Heston, Alan, Robert Summers, and Betina Aten, Penn World Table Version 6.1, Center for International Comparisons at the University of Pennsylvania (CICUP), October 2002.

Johnson, W. Bruce, Robert Magee, Nandu Nagarajan, and Harry Newman, "An Analysis of the Stock Price Reaction to Sudden Executive Deaths," Journal of Accounting and Economics, VII (1985), 151-174.

Jones, Benjamin F., and Benjamin A. Olken, "Do Leaders Matter? National Leadership and Growth since World War II," Northwestern University, 2004.

Kalt, Joseph P., and Mark A. Zupan, "Capture and Ideology in the Economic Theory of Politics," American Economic Review, LXXIV (1984), 279-300.

Karatnycky, Adrian, Ali Piano, and Arch Puddington, Freedom in the World 2003: The Annual Survey of Political Rights and Civil Liberties (Lanham, MD: Rowman and Littlefield, 2003).

Keefer, Philip, and Stephen Knack, "Institutions and Economic Performance: Cross-Country Tests Using Alternative Measures," Economics and Politics, VII (1995), 207-227.

Keegan, John, "Winston Churchill," Time Magazine, World Wide Web: http:// www.time.com/time/time100/leaders/profile/churchill.html, 2003.

La Porta, Rafael, Florencio Lopez-de-Silanes, Andrei Shleifer, and Robert W. Vishny, "The Quality of Government," Journal of Law, Economics, and Organizations, XV (1999), 222-279.

Lee, David S., Enrico Moretti, and Matthew J. Butler, "Do Voters Affect or Elect Policies? Evidence from the U. S. House," Quarterly Journal of Economics, CXIX (2004), 1383-1441.

Levitt, Steven D., "How Do Senators Vote? Disentangling the Role of Voter Preferences, Party Affiliation, and Senator Ideology," American Economic Review, LXXXVI (1996), 425-441.

Lonđregan, John, and Keith Poole, "Poverty, the Coup Trap, and the Seizure of Executive Power," World Politics, XLII (1990), 151-183.

Marshall, Monty G., and Keith Jaggers, Polity IV Project, Integrated Network for Societal Conflict Research Program and Center for International Development and Conflict Management, University of Maryland, 2000.

Marx, Karl, "The Eighteenth Brumaire of Louis Napoleon," Die Revolution (New York), 1852.

Mauro, Paulo, "Corruption and Growth," Quarterly Journal of Economics, CX (1995), 681-712. 
North, Douglass C., Institutions, Institutional Change, and Economic Performance (Cambridge: Cambridge University Press, 1990).

Olson, Mancur, "Dictatorship, Democracy, and Development," American Political Science Review, LXXXVII (1993), 567-576.

- Power and Prosperity (New York: Basic Books, 2000).

Poole, Keith T., and Howard Rosenthal, "The Polarization of American Politics," Journal of Politics, XLVI (1984), 1061-1079.

Posner, Daniel N., "The Colonial Origins of Ethnic Cleavages: The Case of Linguistic Divisions in Zambia," Comparative Politics, XXXV (2003), 127-146.

Pritchett, Lant, "Understanding Patterns of Economic Growth: Searching for Hills Amongst Plateaus, Mountains, and Plains," World Bank Economic Review, XIV (2000), 221-250.

Przeworski, Adam, Michael E. Alvarez, Jose A. Chiebub, and Fernando Limongi, Democracy and Development: Political Institutions and Well-Being in The World, 1950-1990 (Cambridge: Cambridge University Press, 2000).

Quinn, Dennis P., and John T. Woolley, "Democracy and National Economic Performance: The Preference for Stability," American Journal of Political Science, XLV (2001), 634-657.

Romer, Christina D., and David H. Romer, "Choosing the Federal Reserve Chair: Lessons from History," Cambridge, MA: NBER Working Paper No. 10161, December 2003.

Sachs, Jeffrey D., and Andrew M. Warner, "Fundamental Sources of Long-Run Growth," American Economic Review, LXXXVII (1997), 184-188.

Schumpeter, Joseph K., Capitalism, Socialism, and Democracy (New York: Harper and Row, 1950).

Tolstoy, Leo, War and Peace, 1869.

Tsebelis, George, Veto Players: How Political Institutions Work (New York: Russell Sage Foundation, 2002).

Weber, Max, The Theory of Social and Economic Organization (New York: Free Press, 1947).

Wolfers, Justin, "Are Voters Rational? Evidence from Gubernatorial Elections," Stanford GSB Working Paper No. 1730, 2002. 